\title{
COOLEY'S DOCTRINE OF PRIMARY GROUPS ${ }^{x}$
}

\author{
FREDERICK R. CLOW \\ State Normal School, Oshkosh, Wisconsin
}

. . . Since differences of tastes, manners, creeds, languages, and innumerable other variations prevent everybody from liking everybody else, pleasurable fellowship can only take place on the basis of groups in which there is some sort of community of feeling. And so the wise social-center director is now dealing with coteries and cliques, and mainly those which are selfformed, because the business of dividing a crowd into groups which will stick together has not yet been reduced to a science. . . . . .2

When a group is so small that the personality and personal experience of each is known to all, we have a personal group, quite in contrast with the impersonality and anonymity of the city and the larger public of state and nation.

. . . The social instincts operate most effectively only in personal groups. Thus sympathy can largely be depended upon to restrain evil conduct among those who personally know each other. The swindler is often honest and generous in dealing with personal acquaintances. The plundering, corrupt, and corrupting political boss may be a loyal good fellow to his gang.

Here is a neglected chapter in the theory of social organization. Everyone at once admits the importance of such groups as are described above, yet with few exceptions every social theorist has paid no attention to them, doubtless taking them for granted; they have been too commonplace to require notice by the learned.

The first writer to treat the subject with any fulness was Professor Charles H. Cooley, of the University of Michigan. In I900 he began to mention primary groups in lectures to his classes. In 1909 his Social Organization appeared containing three chapters

${ }^{x}$ The greater part of this article is a chapter from a book, Principles of Sociology with Educational Applications, which will be published soon by the Macmillan Co.

? Johnston, The Modern High School, p. 535, C. A. Perry, by permission of Charles Scribner's Sons, the publishers.

3 Hayes, Introduction to the Study of Sociology, pp. 74, 75, published by D. Appleton \& Co. 
on the subject, and these chapters are still the best treatment that has appeared. Professor Cooley applied the adjective primary to such groups because they "are primary in several senses, but chiefly in that they are fundamental in forming the social nature and ideals of the individual." $\mathrm{He}$ makes little use of precise definitions, and he hardly gives any definite mark for a primary group beyond "face-to-face communication." Here, however, is a definition which he has sent in a personal letter and has given permission to use:

I am accustomed to say that the primary group is simply an intimate group, the intimacy covering a considerable period and resulting in a habitual sympathy, the mind of each being filled with a sense of the mind of the others, so that the group as a whole is the chief sphere of the social self for each individual in it -of emulation, ambition, resentment, loyalty, etc.

Cooley devotes an entire chapter to the ideals which primary groups foster. It is by membership in these groups that the gregarious instinct in us develops and we learn how to live as sociable beings. Other writers have expressed the same idea as follows:

. The gang spirit must be spread out but not diluted: the sort of close fellowship it represents is needed as a school of conduct. Young people are not all heroic. No people, young or old, are capable of evolving their own standards of behavior. We all need outside pressure of a fierce and inexorable sort to overcome our laziness or cowardice, make us face the lion in the path, strike out into the cold world upon the quest our soul demands of us.

. . . The most difficult problem of life is to find the right way of treating other people-to make courtesy coincide with independence, respect for others with entire self-respect.

. Precept in this all-important department is of negligible value. Not what he is told to do, but what he sees done and what he finds required of him by a body of opinion whose pressure he cannot escape, is the force that molds a young person's standard of behavior.

. . . . One has only to consider how completely the child is dependent from his earliest days for successful execution of his purposes upon fitting his acts into those of others to see what a premium is put upon behaving as others behave, and of developing an understanding of them in order that he may so behave. The pressure for like-mindedness in action from this source is so great that it is quite superfluous to appeal to imitation. ${ }^{2}$

${ }^{x}$ Lee, Play in Education, pp. 374, 375, published by the Macmillan Co.

${ }^{2}$ Dewey, Democracy and Education, p. 42, published by the Macmillan Co. 


\section{THE SIZE OF A PRIMARY GROUP}

It will be conceded at the first glance, without hesitation, that the sociological structure of a group is essentially modified by the number of the individuals that are united in it. It is an everyday experience-yes, it is almost to be construed from the most general social-psychological presuppositions-that a group of a certain extent and beyond a certain stage in its increase of numbers must develop for its maintenance certain forms and organization which it did not previously need; and that, on the other hand, more restricted groups manifest qualities and reciprocal activities which, in the case of the numerical extension, inevitably disappear. . . . . . ${ }^{\mathrm{I}}$

The number of his fellows with whom a man can maintain easy personal intercourse varies with individual variations, with the conditions of work, and with the time which any body of workmen spend together. Perhaps it does not often exceed eighty, and is normally about twenty or thirty. I do not know of any important attempt to organize mechanical work in relation to that fact, though sometimes the success of a "gang system" may accidentally depend upon it. An American engineer said, I was once told, that the only piece of work which he had thoroughly enjoyed was the making of the Key West Railway, where each pier was placed upon a separate rock in the sea, and was erected by a small and separate group of men who came to know each other thoroughly. In armies it is found necessary, if any measure of comfort and contentment is to be secured, that the officers in each regiment and the men in each company or platoon should be deliberately formed into groups, generally numbering about twenty-five; and one of the responsible organizers of a great insurance company told me that he consciously aims at bringing groups of twenty or thirty officials into regular social intercourse. Those universities are most successful where, by an arrangement of "colleges" or "dormitories," the students are divided into somewhat larger groups; and if no arrangement of the kind has been made by the authorities, clubs or cliques, in forms sometimes inconsistent with other conditions of desirable social life, spontaneously make their appearance. ${ }^{2}$

Simmel's article appeared in 1902, and the book by Wallas thirteen years later, both doubtless independent of Cooley's influence. Other independent evidence on the size of a primary group is found in discussions about the proper number of seats in a schoolroom which is to be in charge of one teacher and the number of teachers in a building which is to be in charge of one principal. Thirty pupils to a teacher is most often named as the

${ }^{x}$ Georg Simmel, American Journal of Sociology, VIII, 2.

2 Wallas, The Great Society, pp. 333, 334, published by the Macmillan Co. 
standard, with a range of from two or three to ten in either direction. ${ }^{\mathrm{r}}$

The principals interviewed have expressed themselves almost unanimously as to the proper size, maintaining that a school should number only so many teachers as the personal acquaintance and influence of the principal can effectively reach; and the outside limit is about thirty, with r,500 children. Many would much prefer to limit the number of children to $1,000 .{ }^{2}$

During the writer's connection with one school the number of teachers has grown from twenty-five to forty-five. This has effected a radical transformation in the character of our faculty simply as a group. Formerly we could all meet for supper and a social time at any one of our homes, and we did so frequently, the members of our families often being included. Now a party for the faculty is an undertaking of such magnitude that it is attempted only once or twice a year, and it has been several years since the children were included. Our daily work is now of greater variety, carried on in more rooms, spread over more ground, and with a more complicated program, so that one of us may not see some of his colleagues for weeks, instead of meeting most of them many times a day as in earlier times. The weekly faculty meeting used to be quite informal and was largely devoted to visiting, many of the women having fancy work along; now it is a business meeting with much routine to put through, and the president holds it to parliamentary rules. Formerly only some unusual necessity would keep one of us away from the general exercises in the morning, lest we lose touch with the school; now it is the exception to attend, and all of the important communications come to us on paper. Therefore, while the number of persons in our group has nearly doubled, the opportunities for getting acquainted with the individual members of it have lessened, with the result that some of us might not be able to call some of our colleagues by name if we should see them among strangers, let alone the members of their families. In fine, we have ceased to be a primary group, chiefly because there are so many of us.

- Ballou, High School Organization, p. 32.

${ }^{2}$ McMurry, Elementary School Standards, p. 186, published by the World Book Co. 
An article in this Journal by Professor R. E. Park, "Human Behavior in the City Environment," shows how the massing of people together changes social control from spontaneous personal accommodation to "rational and abstract principle."

\section{CONGENIAL GROUPS}

One kind of primary group will now be selected for fuller analysis and illustration. Though it is most often given as typical of all, it may be conveniently called the congenial group to distinguish it from the others. Such a group consists of persons who habitually maintain direct communication with one another for the sake of the enjoyment they find in it. They must of course be persons who are in sympathy with one another, or at least without strong antipathies. For this reason the number must be small. An additional member means more than a proportional increase in the probability of discord, for he brings not only one new reaction, but at least as many as there are members already in the group. Thus in a group of three there are three pairs of persons and so three times as many chances of antipathy as in a group of two. In a group of four there are six pairs, in a group of five there are ten, and so on. But even this represents the relationship much simpler than it really is, for the reaction between any two persons is modified by the mere presence of another, after the manner of catalysis in chemistry: the new member brings not only his own reaction with each of the others, but he also causes each of the other pairs to react in a somewhat different way. Then also the larger the group the less the chance for each to express himself, because only one can have the attention of the group at a time. It is also more likely that some will be absent when the others are together, and the absentees will have difficulty in keeping abreast of the others in thought. It is rare, therefore, for a congenial group to include more than half a dozen persons. When it does it is certain to diminish in coherence through the formation of subgroups, and perhaps start on the road to dissolution.

Since a congenial group is a spontaneous growth, without formal organization, its membership is usually shifting and uncer-

${ }^{\mathrm{XXX}}, 593,594$. 
tain. A and B, for example, were students with a room in a central location; C and D were frequent callers; these four had similar work. $\mathrm{E}$ called occasionally and $\mathrm{F}$ rarely; these two were students in other departments. A was popular with all. $B$ would probably not have been in the group if he had not roomed with $\mathrm{A}$; he and $\mathrm{C}$ had little in common, but he and $\mathrm{F}$ enjoyed each other's company when they were by themselves. Somewhat after this manner a congenial group consists of a small nucleus of almost constant members, with a fringe of occasional members who give most of their time to one or more other groups.

The associations of adults are so largely controlled by remote ends that their congenial groups are difficult to identify. An aged person does not fit into new groups easily; he still lives in the groups of his earlier life, keeping in touch with them by indirect communication; the casual observer merely sees the absence of any strong interest in surrounding persons. Children, on the other hand, spend much of their time in congenial groups. A teacher can find no more fascinating study, nor one more helpful professionally, than these natural groupings which children form for themselves. For boys' groups of the better sort the following accounts are typical:

Five boys between the ages of nine and thirteen got together to work. All would go to one boy's home and help him with his chores, then go on to the next. This was fun-work turned to play. The leader of this group was not the oldest nor the largest, but one who could look serious and command-always could think of new stunts to do. He it was who proposed the building of a shack in one of the back yards with scraps of lumber picked up or given to them. ${ }^{x}$

A group of six boys was established in the seventh grade through an interest in outdoor sports, especially baseball, hunting, and swimming. When at leisure they were always together. At parties and social affairs they formed a clique. When one member was ill the remaining five took turns staying at the bedside during the night. One of the boys fell and broke his arm; the others took his paper route, delivered the papers and gave him the money. They would also come to play with him and cheer him up. One of the members had work to do before he could come out to play; the others would help him do it. But the unity of the group was not always one of harmony; they

${ }^{x}$ This and other quotations for which references are not given have been contributed by friends of the writer. 
had frequent quarrels, though never very serious ones. They hated an untruth. When they found that one of their number had told a deliberate lie they punished him severely.

Last summer I watched a group of boys ranging between nine and twelve years of age on a playground near my home. Almost any time of day they could be seen-the same group each day. Once I noticed a strange boy about the same age as the rest come and ask to join in their game. But they refused blankly-no outsiders allowed. On another occasion a boy who had had more practice in playing ball than any in this little group came and offered his services as pitcher. But they refused him, even though they realized that he might be a great help in their play. One morning when the group gathered for play one of the members was not present. They all ran to his home and found that he had been set to the task of piling some wood in a shed. So they pitched in and helped him pile the wood. That done, they all returned to their play. One of the boys accidentally broke a window. They all contributed to the cost of replacing it, so that he had only his share to pay.

The gang spirit is strongest in the average boy during his thirteenth, fourteenth, and fifteenth years, when he is in the seventh, eighth, and ninth grades. Here is the way one writer describes this stage in a boy's growth:

The boy begins . . . . to feel more strongly than before the necessity of meeting certain other boys every day - to play a game, if favored by surroundings and good play traditions, but anyway to meet, for purposes which seem to him sufficient. His life is now in this companionship; it has become his milieu, his social complement, his world, as necessary to him as a mother to a little child. This relation pervades his life and everything he does, If he walks, swims, rides, makes jokes, converses, it is as a member of a horde. . . . .

. . . His paramount desire now is to belong: to live and act, succeed or fail-to suffer if need be-not as an individual, but as a member of a social whole made up of boys of his own age; and the effects of this new desire are seen in everything he does. . . . . .

\section{GIRLS' GROUPS}

Girls are less obtrusive than boys, less noisy, so that their congenial organization has been less noticed by adults. But their groups exist just as universally as do those of boys, and they are just as important educationally. Groups of girls are smaller than

${ }^{x}$ Lee, Play in Education, pp. 319, 320. 
those of boys, and less stable; they are less likely to grow into formal organizations. Here are two accounts of groups composed of older girls:

I belonged to a group with three other girls. We were all about the same age. The group started in the early part of the seventh grade. At school we were always together and paid little attention to other pupils. The teachers tried to get us to mingle with the other children, but without success. Two of us took piano lessons, another vocal, and the other played the violin; therefore much of our time outside of school was spent in practicing music together. We could all roller-skate, and so on Saturday afternoons we often went skating. One of our rules was that when we were going any place we must be there on time. No one dared to lie to another member of the group. These rules were always obeyed. When we graduated from the eighth grade two of us came to the normal and the other two went to the high school, so our group was broken up.

In a boarding club of eight girls there is a primary group of four. They became intimate while waiting for meals. In time they found that they had similar tastes for literature. At first they merely read and discussed literature at odd times; then they arranged to spend one evening a week together. Although these four enjoy the company of the eight at the table, yet when the meal is over the four go off together. One of them was invited to a party and wished very much to attend it. When she learned, however, that the other three were not invited, and saw how downcast they were over it, she declined the invitation. This is a sample of the loyalty to one another which they often exhibit. The strongest of the girls is giving the others not only her love for poetry, but also her confident bearing among people.

The following reports come from young women as a result of their experience in teaching, and therefore describe groups of younger girls:

Girls form groups for the purpose of playing, sewing, etc., and sometimes for the sole purpose of having companions in whom they can confide. In girls' groups we usually find a great deal of gossiping going on. Boys' groups are harder to break up; the members are more loyal to each other; they work more as a unit. Girls like to have their own way, therefore there is constant clashing in a group.

In my fifth-grade practice class there is a group of five girls that has grown into a formal organization. The purpose is to make dolls' dresses. They meet at the homes of the members on Tuesdays, Thursdays, and Saturdays. On Saturdays the sewing ends at three o'clock and they go in a body to the matinée. I was invited to one of their meetings. The chief topic of 
conversation was the merits and demerits of their practice teachers. They decided, among other things that afternoon, that they would make Miss C. "mad" by all chewing gum and writing notes.

There is some clashing among the girls, and usually over trivial matters. Occasionally a girl will come to me and ask for permission to change her seat; then, when asked the reason why, will say that she and her seat-mate are not on the best of terms. Of course, I never give the girls permission for such a reason. Instead $I$ arrange to have the two girls deal with each other in some way, and before they know it they are as good friends as ever. I have never known such a case to arise among the boys. They seem to settle such matters among themselves.

But some girls' groups are as lasting and harmonious as those of the boys.

I once knew a group of three girls. There seemed to be no reason why they should go together except that they simply enjoyed each other's company. They would read, play with dolls, and sew. One was a great reader, and often brought a book with her. Then the other two would sew while she would read. Two of the girls went to a convent school and the third to a public school, but this enforced separation seemed only to strengthen the group. When evening came they would meet and relate the experiences of the day; as much as possible of Saturday and Sunday would be spent together. By and by one of the girls moved away, but this separation was overcome by almost daily letters. Now, after the lapse of twelve years, this group still exists, kept together by correspondence and occasional visits.

There are four girls who are always together. They live in the same town and were friends before coming here. Misses W. and C. became acquainted while in the third grade; they were together through the grades and high school. Misses A. and C. were together through the grades in another school. These four girls formed one group during high-school days. They came to normal at the same time, roomed at the same place, took up the same course in school, and consequently are in all the same classes in school. They sit near each other in both the study-room and the auditorium. They are loyal to each other. If one is absent the others resent any uncomplimentary remark about her.

One of the girls was to sing in a quartet. It was necessary for her to go early to practice, but there was some work about the room which she was to do. The other girls did her work as well as their own so that she could go.

In the same way the other ideals are present, such as truthfulness, kindness, and lawfulness or abiding by the wish of the majority; also freedom, for although these four girls co-operate in all of their work there is still the feeling that they can do what they wish. 
It is rare to find both girls and boys in the same group if beyond kindergarten age. Whenever that occurs the girls presumably have some masculine qualities, or the boys feminine qualities, or else the group is functional rather than primary.

When $M$. was a grammar-grade pupil she played baseball with the boys. She could run fast and had plenty of nerve, so was a good player. When she neared the end of the eighth grade one of the boys said he hoped she would not pass so that she could continue on their team.

Thirty-five years ago, about, a group of boys and girls in the intermediate grades called themselves the KKK's-Ku-Klux-Klan. They read The Scottish Chiefs by themselves, and as a result of it formed a plan to free Scotland when they grew up. Some of the members of the group still exchange letters and so keep up the old group feeling. One of the women went recently with her son to visit one of the men.

\section{CONGENIAL GROUPS IN SCHOOL}

The following account, written by a teacher, gives a careful analysis of the grouping of the children in a rural school:

In this school there were fourteen families represented, and at school the children formed seven play groups. At noon in winter when the children ate their lunches in the schoolhouse it was an easy matter to pick out the different groups. Only about half of the children belonged to decided groups: Sometimes they were grouped one way, and at another time some other way. Two little girls never belonged to any group. The same was true of one boy.

Of the seven distinct groups, one was a group of two boys, one fourteen years old and one sixteen. These two boys were always together, and if one happened to miss a day, which was seldom, the other seemed entirely lost, and did not want to take any part in the play with the rest. Another group was made up of four boys: one aged eleven, two thirteen, and one twelve. Three of these boys always formed a group, and the fourth was sometimes a part of the group and sometimes not. He was rather a quarrelsome boy. Another, of three boys, eleven and twelve years old, two of them being brothers.

Three girls, eleven, twelve, and thirteen, formed a group. Three girls, two twelve years old, and one ten, formed another group. Two little girls who started to school the first year I was here soon formed a group, and still keep together.

The two little girls who were not members of any group seemed to be different from the others. One was a member of the family which was rather looked down upon by the other families. The other was a strange child. 
She never seemed to be able to take things in the way they were intended. She wanted to look into the other girls' dinner pails, and would do it every chance she got, even though she knew it was wrong. She would try to sit down in a seat even when it was already crowded.

The boys' groups were the more permanent. The girls shifted around more. Sometimes the group would be made up of four and then again these four would make two groups.

It goes without saying that congenial groups are influential in a school. All that personality counts for applies with special force to the group of persons who meet with such close intimacy. The practical question is about the policy which the teacher should adopt toward them. The ordinary elementary school requires that a large proportion of the work done by pupils be their individual effort. While every pupil should be trained to work by himself, it must yet be recognized that the greater part of the world's work is done by groups of workers and that the majority of young people show a keener interest in group work than in individual work. Often work which the teacher assigns with the expectation that it will be prepared by each pupil independently is in fact worked out in groups, with more or less of concealment, according to the teacher's attitude toward that practice. Accordingly some of the newer types of schools allow more space in the program for such co-operative enterprises as chorus and orchestral music, pageants, plays, games, dances, publishing a school paper, running a cafeteria, housekeeping, and large pieces of construction work. The joint effort involved in such activities will enlist congenial groups and, under supervision, will have a peculiar educative value.

Testimony shows that the presence of congenial groups, even when their aims are not specially bad, has its drawbacks and even dangers. The first statement quoted below is from a teacher of considerable experience and more than ordinary success:

I think a school that is broken up into "sets" and "cliques" is in a deplorable condition. A good teacher smooths away these barriers and brings the whole room into harmony. A teacher who would deliberately foster cliques in school I should think to be on a par with the teacher who has pets and shows favoritism. Cliques are all very nice for those who are inside, but how about those who are outside and see the group go off with 
arms about each other whispering secrets? Is it not the teacher's duty to see fair play-equal advantages to all ?

I do not think that play groups should be openly recognized. The teacher can make use of them to some extent, but should endeavor to make the pupils of the school one group. Effort by the teacher to get into the groups may result in loss of prestige. The principal of the high school I attended never fraternized with the pupils, yet he was as good a teacher as I ever had and kept his position seven years.

When J. was in the sixth grade he was in a congenial group of boys and girls. The teacher favored this group so much as to arouse the antipathy of the remaining pupils. The next year J. and others of the group failed in their school work because they had forgotten how to study. He attributed his weakness in mathematics to the easy requirements of that sixth grade.

But the weight of testimony is decidedly in favor of recognizing the groups, provided it be done with care, especially avoiding favoritism. Congenial association is something no one can be altogether deprived of and retain a wholesome mind. To the child it is the breath of life; he must be immersed in it constantly as he is in the air; older persons can do without it longer because they have learned to draw mental nourishment by indirect communication.

Take the case of the new child in school who has no acquaintances there. He is enrolled, assigned to a seat, draws books, goes to recitation, and the like. These, of course, are what he comes for and may be all right in themselves, but they are not enough: they are formal. There must be companionship, the give and take in talk, smiles, laugh, play, and all the spontaneous things that come in informal communication between friends. If the hours pass by without these things the child has a feeling akin to suffocation; he bursts out crying without apparent cause, goes home with a lump in his throat, and hates school. On the other hand, if the child happens to meet a congenial companion or two before the school is called to order, is permitted to sit near them, and has occasional opportunities for informal intercourse with them, then friendly glances and smiles can be exchanged in the midst of the formal things, he breathes freely in the assurance that others who understand him are at hand, and goes home delighted with school. 
All the children belonged to groups and the spirit of the school was wholesome. The group interests were in part interests in specialties. Four girls were musically inclined, three others were interested in needle-work; the younger boys and girls played games together, while the two older boys were always together, playing ball, or hunting or fishing. The teacher tried to get them to play together, but without success, and she finally admitted that "they all seem perfectly happy as they are."

The groups did not cause any trouble; the children were not so divided but that all could join in a game and play. They were all quite fair, even with the three children who were in no group. Groups are a help to the teacher. If a teacher recognizes them, things will work out harmoniously; otherwise it will be like bringing sharp edges together. Whenever there is any group work, those agreeable to each other should work together to get the best results. If the teacher would avoid trouble, she will not have two people sit together who cannot get along well. In this school there were no individual desks, and two children had to sit together. At first two boys who had sat together constantly found fault with each other; little things, that would never have been noticed ordinarily, were exaggerated. After changing their seats they were both good in school, and neither found fault with his new seat-mate.

The Sister who had charge of the boys was interested in child-study and understood primary groups. She allowed members of groups to sit near each other and study together. In contests the groups were pitted against each other. The leaders of the groups were the monitors of the classes.

Four girls have been in the same classes for six years, and have been a congenial group throughout that time. They dress alike as far as possible. They strive to keep their grades above a certain mark. When one member is away the others write a group letter to her. It is rare that one of them says "I" in speaking of her plans or work; it is nearly always "we." But they are not entirely interested in themselves. On May Day they make it a point to always remember two old ladies with May baskets. On St. Valentine's Day their efforts are directed toward having everyone in the school receive at least one valentine. They set the standard of work in whatever class they are members. One boy, naturally bright but lazy, makes a special effort to keep up with the "Quartette." That group is always recognized by the teachers because of the good influence it has on the other children.

When I was about ten years old I attended a school which was divided into two groups, the North and the South. The teacher fostered these groups by letting the members of each group sit together, also by acting as the leader now of the one and now of the other. The rivalry between the groups was friendly. The next year the new teacher mixed the seating of the groups. 
There was constant disturbance, such as throwing notes and whispering. The outcome was a war between the North and South which was not a friendly rivalry but a real combat.

\section{AT BOARDING SCHOOLS}

Then there is the girl who goes away from home to school for the first time and has a week of homesickness. Does not the theory of congenial groups offer the best explanation and the proper remedy?

She leaves the congenial groups in which she has lived, and an interval elapses before she can find new ones. The management of the school can do much to shorten that interval. It can arrange to have the girls thrown together in various combinations so that each one will meet many others, with occupations requiring communication and with opportunity for informal conversation. The sooner this is done the better, and at all events it should be before the first Sunday or holiday.

The process by which a hundred girls, hitherto strangers to one another, assort themselves into congenial groups is one of exceeding intricacy. Between every pair that meet the association must be mutually satisfactory or else it will remain formal, and it is almost necessary that the satisfaction extend to all the members of the groups to which each one of the pair belongs; one girl may like another but be obliged to hold aloof because she clashes with one of the other's friends. Each must learn how to meet each of the others whom circumstances place her with, and to do it in such a way as to avoid the asperities and find the durable satisfactions. The school can help in this by bringing together in the first week as many different groups as possible for singing, basket-ball, tennis, hikes; also the adherents of the various churches, the devotees of orchestral music, drama, and other arts. It is not necessary to begin serious work in this first week that is so full anyway, but just enough to bring the new members together for mutual acquaintance. Most of the groups thus formed are only temporary, but they supply acquaintance in place of isolation so as to minimize homesickness and promote the formation of permanent groups. 
Large schools often divide their students into groups of from a dozen to twenty and assign one group to each member of the faculty as an adviser. The adviser is expected to develop congenial association with the members of his group as far as possible and at least get into direct communication with them.

Fraternities and sororities are organizations whose chief function it is to promote congenial association among students by bringing together a selected membership in a house adapted to the purpose. Such organizations have existed in the colleges for more than a century, usually, though not always, with the approval of the faculty. In the early years of the twentieth century they grew rapidly in high schools. But the school authorities in most places adopted measures of repression; when high-school students withdraw by themselves in small exclusive groups they tend to develop a snobbish attitude toward outsiders that is intolerable; they still need the corrective of free association with persons both older and younger than themselves. In the colleges and universities, however, especially the larger ones with thousands of students away from their homes, fraternities and sororities meet a real need. But that need, it must be admitted, is in some institutions adequately met by other agencies.

At C. Hall in our university some of the girls who were there last year are appointed as advisers to the Freshman girls. During vacation the names and addresses of two or three Freshmen are sent to each adviser, who then writes to each of her advisees and arranges first of all to meet them at the trains.

There is also an all-university system of advisers managed by the Junior class girls in behalf of the Freshman girls. "The duties of the advisers," says the Bulletin of the Self-Government Association of the Women Students, "are to aid the Freshmen in adjusting themselves to their new life and to advise them concerning their choice of college activities."

. . . . There has never been set forth a good reason for the existence of the high-school fraternity. The college students are older and capable of exercising more judgment. A real need is supplied to young men and women away from home by offering a substitute for home life. High-school students are at home, and are too young for club life. Whatever may be said in favor of college fraternities, relative to establishing desirable social standards and for the benefit of students, is not applicable to high-school pupils because of their immaturity. ${ }^{x}$

${ }^{I}$ R. C. Hill, Educational Review, XLIII, 170. 


\section{DISCIPLINE}

It often happens that hard cases of discipline have their roots in the deliberately chosen policy of congenial groups-"gangs" as they are then called. It is the group that must be dealt with, though it may sometimes be reached through its leader. A requirement that would seem arbitrary when imposed on an individual may seem entirely just when imposed on a group. The promise of a group can be trusted more than the promise of an individual, because the members will look after one another.

A gang of youngsters were transferred to our school from a school where they had had their own way. They started in to run things, even making use of knives to overawe the others. Two of them told me in the most amiable way how they had held up a boy before coming to us. They had the idea that such conduct was honorable. They yielded slowly and reluctantly to better training, but finally became as good boys as any we had.

Twelve girls, sixteen to eighteen years of age, developed the spirit of the clan. They called themselves the "Batty Bunch," and wore as a badge a pin in the shape of a bat with spread wings about three inches in width. They studied just enough to avoid serious consequences, but always made something better than the passing mark. Their favorite enterprise was to go out in the evening on some kind of an excursion, perhaps an automobile ride into the country. The president of the school reproved them, singly and in groups. He finally exacted from them the promise that they would stay in their rooms and study until ten o'clock. They obeyed the letter of the law, but broke the spirit of it by studying until ten o'clock and then going to the street to have a good time. When the president found this out he prepared to take severe measures. But an elderly man of the faculty, who had a keen insight into human nature, offered to take charge of the "Bunch" and guaranteed their good behavior. The president at once handed him a list of the twelve names and wished him success in his undertaking. Their new sponsor called the girls into his office, read their names, and set the situation before them. They accepted it with pleasure and promised to behave. He insisted on just one thing: each member of the twelve must report to him every morning what she did during the evening before.

Thereafter the "Bats" caused no special trouble. They kept the spirit as well as the letter of the promise to their sponsor. They graduated from the normal school in due time and took positions as teachers, and everyone was pronounced a success by the superintendent with whom she worked. In a few years some married and made good homes. All of the others graduated from some university or college. The teacher who took the responsibility 
for the conduct of the girls testifies that he was helped in a large measure by his wife; she gave the girls a kindly welcome to her home and never preached to them.

The child in question is a boy about ten years old, of foreign parentage, nervous and rather passionate in disposition. He was late in entering school, and was therefore looked upon as an outsider by the groups already formed. This made him lonely and discontented, though at first he seemed to find pleasure in the school work itself. In a few days, however, his attitude underwent a marked change. He became inattentive and kept close track of the clock in the rear of the room. It was apparent that his thought was becoming centered on something separate from the school and its work. The question, of course, was, what was he doing and where was he going? A little inquiring and watching brought out the fact that, through selling newspapers, blacking shoes, etc., he had gotten in with a gang of boys who were notorious for bad behavior of various kinds, and that he was being made over into one of them about as rapidly as possible. His craving for companionship was being satisfied.

I said very little to the boy himself, but by watching him on the streets whenever possible and consulting others who knew him I decided that his original motive in going with those boys was to get money. Then I undertook to meet him on his own ground. We were making raffia baskets about that time and I offered to buy his basket from him. He became interested immediately. He worked before and after school and at many odd times in order to finish his basket. Some other boys were also hard at work on baskets, and naturally a friendship sprang up between them all. Our boy discovered that these boys knew something, that they liked to do things, and above all that they could do things as well as those outside fellows. An outdoor picnic helped things along, and soon he was one of this-to him-absolutely new group. The effect was evident in his entire attitude toward his work.

I have in mind a lad of eleven years. His teacher said he was a chronic case of sulks. He was the only child of a prominent city physician, and could have had all the things that ordinarily delight a boy's heart. Other well-dressed and good-mannered boys in his grade in school possessed no attractions for him. He did not respond to their friendly advances, but kept out of their games and by himself.

One winter's night he came in late wearing a dirty, ragged suit of clothes. He was made to change them, but gave no reason for his strange appearance. Again the same thing happened. A teacher of large soul and detective characteristics followed this clue and discovered the keynote of D's character. Over on the other side of the city was a group of boys who were ragged, unkempt, the gamin of the streets, boys who slept in ash-barrels and doorways. To these boys $\mathrm{D}$ was wont to go, using his money for food for them, giving them his choicest books, and occasionally wearing home their 
clothes that they might have his. To these boys he was a young prince and to him they were the real thing. Here there was no outside coat of fine manners to annoy him, no rivalry in studies, no snobbishness. He found them self-reliant, fearing nothing and self-supporting, though by means often questionable. In short, D had found his primary group. They needed him, but he also needed them. He loved reality and not pretense. So were the cravings of his boy heart ministered unto, while his sense of brotherhood found expression.

\section{CAN CONGENIAL GROUPS BE CONSTRUCTED?}

Since congenial groups are so potent to either hinder or advance the interests of a school, the question arises how far a teacher may work in such a group among his pupils and so help to determine its policy; also whether he may not bring together the pupils who will make a group of a desired kind. The testimony is conflicting on both of these points. Doubtless something depends on the age of the pupils and much on the personality of the teacher. Some teachers should never attempt it, but they may nevertheless be good teachers, like the principal mentioned on page 337. The writer of the first selection given below is the principal of the Boston Normal School.

. . . Neither society as a whole nor its personification in the teacher can say: Go to; let there be groups. Let us put so many in one group and so many in another. Let us select individuals according to their capacities, and give them work that will be suited to their needs. No, a real social group cannot be reduced to a mere instrument of the teacher, a means or a method for accomplishing certain preconceived purposes. It is necessarily too many-sided for that. . . . . I

After the graded school had been in session a few weeks a boy from a rural school entered the sixth grade. He was backward in his school work the remainder of the year and seemed little interested in matters connected with the school. The following year the new teacher seated him with the most brilliant pupil in the grade, with the result that the two boys became close friends. The new boy began to take more interest in things, first in his studies, then in the games. Before the end of that second year he was enjoying school and doing work which won him the respect of the other boys in that room.

I have found that up through the fourth grade it is important that the teacher be included in the "we" feeling. The children like to have some

× Scott, Social Education, p. r6, published by Ginn \& Co. 
older person join in with them and be interested in all they do. But in the fifth grade and beyond it is not so important. The children then begin to assert themselves and want to be left alone. I know a case where a seventhgrade teacher, a young man, sought to gain admission to a group of boys. As soon as he came on the playground there was an air of aloofness; anyone could see that their play was half-hearted. One day after playing with them a few minutes he went into the schoolroom. While he was still within earshot he heard one of them say, "Gosh, I hope he stays there and don't come buttin' in again." The teacher took the hint and did not try to play with the boys after that.

I do not believe that groups can be constructed; they must grow. The group is composed of kindred spirits, and persons who are not possessed with this spirit cannot become members. The children themselves must decide who is to be in their group; a parent or teacher cannot do it. I remember my grandmother wanted me to play with three girls, and the girls' mammas were equally anxious to have me play with them because the other children in the village were Protestant. But I did not like the three girls and they had no love for me; I preferred the society of two Protestant girls in spite of my grandmother's entreaties.

When I was seven years old we had a Sister for a teacher who was a member of our congenial group. At recess she played games with us. We told her all our little tales of woe and she sympathized with us. The order in the room was as nearly perfect as possible. We knew the rules and were very careful not to break them lest we should displease Sister B. The next term our beloved teacher didn't return. The new teacher had been in the room only three hours when we decided that we could not have her in our group. The first thing she did was to change the seating. Now all of "us" had been sitting together, and when we were separated we vowed revenge. Not a lesson would we study; we did everything we could think of to annoy her. It seemed to us that she was trying to make things disagreeable for us.

\section{CONGENIAL ASSOCIATION APART FROM GROUPS}

The congenial groups described in the foregoing extracts have been groups of children or young people, for, as has already been noted, the grouping of mature persons is obscured by their pursuit of remote ends. It might be true to say that most men in middle life do not belong to congenial groups.

Men do not usually have congenial groups, but I know two men, farmers, who were inseparable. Every evening when their work was done they would meet and talk. When one went to town the other usually managed to go too. 
On Sunday they would stroll over their farms, or take a walk through the woods looking for game or berries, or do something that would keep them together.

But most men nevertheless have a great deal of what might be called congenial association, provided they were trained to it by membership in congenial groups during their childhood. They have the "frequent face-to-face communication for the sake of the enjoyment they find in it," only they get it incidentally in the pursuit of more serious ends. They rarely form the intimate friendships of their earlier years; both the need and the capacity for that sort of thing have passed away. They have learned instead to meet various kinds of people, strangers as well as old acquaintances, in an easy, enjoyable sort of way; from this comes most of whatever growth they make in opinions, ideals, and interests.

The traveling salesman is perhaps the best example of this. $\mathrm{He}$ gets his congenial association, not with any small and constant group as does a child, but with the thousands whom he meets incidentally, some by appointment and some by chance, many whom he never met before and will never meet again. Ability to do this is the condition of success in his vocation. It is not enough to merely appear, for politeness' sake, to enjoy meeting all these people; the true traveler really does enjoy it.

This congenial association not only comes incidentally in the pursuit of serious ends; it has its function in the pursuit of those ends themselves. Communication on the most serious business in the world can accomplish its purpose of leading to likemindedness and concerted action only in so far as there is sympathy between the parties, some common ground to start from. Now sympathy is easiest started in matters of mere enjoyment. Note the story-telling and laughter that usually go on between two or more men in the midst of their consideration of sober affairs. In this respect Abraham Lincoln was typically human. Then there is the eating together, and the drinking, and the smoking; the automobile ride, the game of billiards, the theater partyall ostensibly for mere enjoyment; but in the mind of the promoter they are often a means of establishing sympathetic relations as a basis for communication on weighty matters. 


\section{EDUCATIONAL APPLICATION}

In education, as well as in business and politics, congenial association must hold a large place, because without it communication for serious ends is not effective. If the merchant will buy of a traveling salesman what he would never order by mail from a catalogue, much more is the sensitive mind of the child dependent on direct communication for what is learned. The teacher is more of a necessity to education than the salesman to business. Books, periodicals, and correspondence schools can never do as much of the teaching as catalogues and mail-order houses do of the selling. Often we hear a pupil say, "I cannot understand this when I study it by myself, but I can when it is explained in class." Moral and aesthetic truths especially are learned through the sympathetic touch of personality; they must be seen actually at work in the life of another person; the learner may perchance then discover them at work in his own life. The things of durable value must be floated up to the threshold of attention by the agreeable trifles of congenial association.

Herein lies the reason for one of the qualifications which is almost indispensable for success in educational work. Especially superintendents, inspectors, and supervisors must be adepts at developing congenial association apart from definite groups. They need to be able to get into sympathetic relations with all kinds of people. Unless they can mix enough good fellowship with their suggestions and directions to make interviews with them agreeable they are liable to become taskmasters, or perhaps only detectives. The same is true of classroom or grade teachers, only they have a definite group of children to meet and therefore more time to develop a working adjustment with each child; but that also means time for the novelty to wear off and for antipathies to develop. The supervising officer with a subordinate whom he cannot bring into sympathy with himself is usually able to avoid personal interviews. But the teacher has no such escape: an adjustment must be made with every pupil in the room, and the presence of one pupil between whom and the teacher there is a fixed antipathy may make congenial association between teacher 
and pupils in that room an impossibility, and so reduce the work for all to mechanical grind.

This subject of small groups and the reactions which occur between persons who meet face to face is deserving of investigation. Students who are looking for thesis subjects in sociology or social psychology are invited to take notice. It makes a universal appeal, it is fundamental to all social organization, and its professional importance extends to other occupations besides that of teaching. Girls' congenial groups are especially suitable for firsthand study because there is practically nothing in print about them.

\section{REFERENCES}

Bernheimer and Cohen, Boys' Clubs. Chapter $\mathrm{x}, \mathrm{pp}$. 8I-94, treats of girls' clubs.

Cooley, Social Organization, pp. 23-57.

R. C. Hill, Educational Review, XLIII, r68-9r, "Secret Societies in High Schools."

Ellwood, Sociology in Its Psychological Aspects, p. 346.

Ferris, Girls' Clubs.

Fiske, Boy Life and Self-Government, pp. 107-18, 169-91.

Giddings, Principles of Sociology, p. 376.

Gunckel, Boyville.

Hayes, Introduction to the Study of Sociology, pp. 74-77.

Johnston, The Modern High School, pp. 498-5I6; J. C. Hanna, "HighSchool Fraternities and the Social Life of the Schools."

King, Education for Social Efficiency, pp. I4I-49.

King, Social Aspects of Education, pp. 236-63.

O'Shea, Social Development and Education, pp. 248-64, 295-315, 493-98, 509-I5.

Puffer, The Boy and His Gang.

School and Society, IV, 49, 292, 313, 363, articles on excessive sociability among students.

Scott, Social Education, pp. I-22, 94-101, 102-69.

Smith, An Introduction to Educational Sociology, pp. 49-56. 